\title{
Associations between chronic pelvic pain and psychiatric disorders and symptoms
}

\author{
Ana Carolina Franco de Carvalho1, Omero Benedito Poli-Neto ${ }^{1}$, \\ José Alexandre de Souza Crippa1,2, Jaime Eduardo Cecílio Hallak1,2, Flávia de Lima Osório1,2 \\ 1 Ribeirão Preto Medical School, University of São Paulo (FMRP-USP), Ribeirão Preto, SP, Brazil. \\ 2 INCT Translational Medicine, National Council for Scientific and Technological Development (CNPq), Brasília, DF, Brazil.
}

Received: 1/16/2015 - Accepted: 9/20/2015

DOI: 10.1590/0101-60830000000042

\begin{abstract}
Background: Chronic pelvic pain (CPP) is a complex condition wich is associated with emotional factors, specially depression and anxiety. Objectives: To make a systematic review to provide a detailed summary of relevant literature on the association between CPP and different psychiatric disorders/symptoms. Methods: A systematic review of articles in the international literature published between 2003 and 2014 was performed in the electronic databases PubMed, PsycINFO, LILACS, and SciELO using the terms (chronic pelvic pain) AND (psychiatry OR psychiatric OR depression OR anxiety OR posttraumatic stress OR somatoform). The searches returned a total of 529 matches that were filtered according to predefined inclusion and exclusion criteria. A total of 18 articles were selected. Results: The investigations focused mainly on the assessment of depression and anxiety disorders/symptoms, with rather high rates (17-38.6\%). Depression and anxiety symptoms were more prevalent among women with CPP compared to healthy groups. Comparisons between groups with CPP and with specific pathologies that also have pain as a symptom showed that depression indicators are more frequent in CPP. Depressive symptoms tend to be more common in CPP and have no particular association with pain itself, the core feature of CPP. Discussion: Other aspects of CPP seem to play a specific role in this association. Anxiety and other psychiatric disorders require further investigation so that their impact on CPP can be better understood.
\end{abstract}

Carvalho ACF et al. / Arch Clin Psychiatry. 2015;42(1):25-30

Keywords: Anxiety, comorbitidy, cronic pelvic pain, depression, psychiatric.

\section{Introduction}

Chronic pelvic pain (CPP) is a common and disabling condition among women in reproductive age $e^{1,2}$ and is currently regarded as a public health problem ${ }^{3}$. International and Brazilian studies report prevalence rates of CPP ranging between $4 \%$ and $25.4 \%{ }^{1,4-8}$. Although there is no complete agreement about the definition of CPP, the condition is characterized by the presence of continuous or intermittent pain in the lower abdomen (below the navel) and/or in the pelvis, persistent for at least six months, not exclusively associated with menstruation, sexual intercourse or neoplastic disease, severe enough to cause disability or functional impairment, and requiring clinical and/or surgical treatment ${ }^{9-13}$.

CPP is a complex condition of usually unknown etiology and influenced by or resulting from the interaction of various systems, including the gastrointestinal, urinary and genital tracts, and neurological and psychological aspects ${ }^{2}$. In up to $60 \%$ of cases, CPP is associated with emotional factors ${ }^{14}$, most commonly represented by depression and anxiety ${ }^{15}$. Researchers have been trying to identify the role played by emotional factors in the onset and maintenance of CPP, regarding such factors both as possible consequences of the chronic condition and also as etiological agents.

In this direction, evidence exists about the causal relationship between psychological factors and CPP, as women with the condition present significantly higher rates of psychiatric disorders as compared to control groups ${ }^{16-18}$. Other authors still report that negative mood and emotion can cause or increase pain ${ }^{19}$ and that the experience of pain, as a personal and subjective phenomenon, is probably affected by emotional states and, therefore, by psychosocial factors ${ }^{8}$.

Other investigators suggest exactly the opposite. To them, it is the context of chronic pain itself that favors feelings of frustration, preoccupation, anxiety, and depression ${ }^{8}$. Women with CPP have to deal with the loss of a healthy and active body and reach a state of dependence and disability that may be responsible for changes in affective, family, social, and sexual dynamics, thus having a negative impact on quality of life ${ }^{20}$. A study by Roth et al. ${ }^{21}$ investigated this hypothesis through the comparison of women with CPP and with other conditions involving chronic pain, especially migraine. Their findings showed that women with CPP were more dissatisfied with their marriage and capacity for sexual intercourse; however, no differences were found in regard to indicators of depression and anxiety or personality traits. These data suggest that, in general, when CPP patients present with psychological disturbances, these are likely to reflect the effects of chronic pain.

It should be noted, however, that many studies had inconclusive results because of the methodology or design adopted, and that the role played by emotional factors in the onset and maintenance of the condition remains largely unknown $8,20,22,23$.

Despite the large number of studies investigating the association between CPP and different psychological and psychiatric aspects, no systematic reviews or meta-analyses have been published to date dealing with this topic and contributing to expand the comprehension of this association.

\section{Objectives}

The objective of this study was to perform a systematic literature review of articles published over the last 12 years in order to identify possible associations between CPP and different psychiatric disorders and/or symptoms.

\section{Methods}

This systematic review was conducted in accordance with the PRISMA (Preferred Reporting Items for Systematic Reviews and MetaAnalyses) Statement and the guidelines of the Cochrane Handbook for Systematic Reviews of Interventions.

We made a systematic search for articles published between January 2003 and July 2014 indexed in the online databases PubMed, PsycINFO, LILACS, and SciELO using the search expression (chronic pelvic pain) AND (psychiatry OR psychiatric OR depression OR anxiety OR posttraumatic stress OR somatoform). The searches returned a total of 529 matches that were filtered according to predefined inclusion and exclusion criteria, as shown in figure 1. 


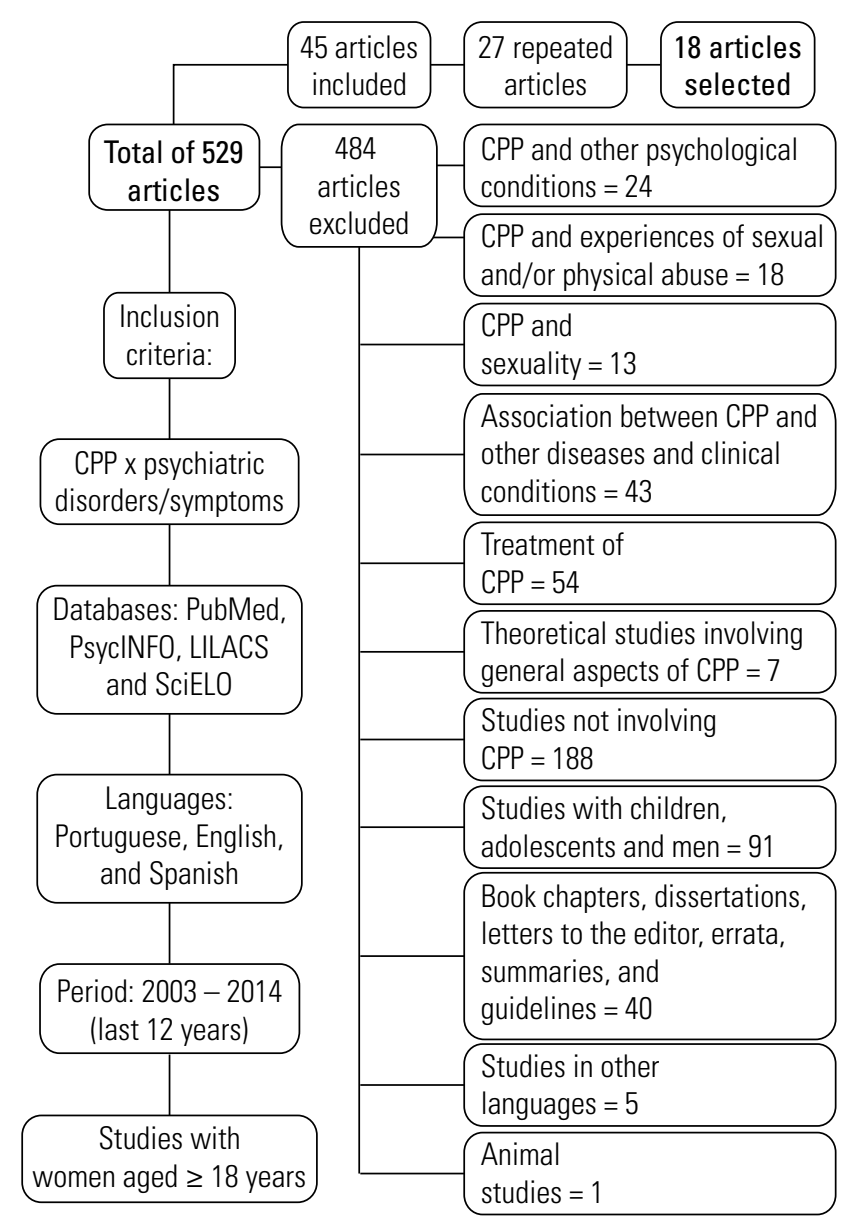

Figure 1. Flowchart showing the procedure of article selection and inclusion/ exclusion criteria.

\section{Results}

A total of 18 articles were selected and independently examined in respect to their adequacy for inclusion in the review by two psychologists and mental health researchers. From these, five studies ${ }^{24-28}$ used an observational descriptive design and the remaining 13,20,21,29-38 used a case-control design. Most of the studies were conducted in the United States $(n=6)$ and Brazil $(n=5)$. Table 1 provides data on the studies' design, country of origin, and main sample characteristics.

The clinical groups with CPP assessed in the studies included samples ranging between 12 and 713 subjects, with mean of 94.4 and median of 44 . Subjects had a mean age of 35.6 years and large variations in education. Most of the studies established the presence of CPP through clinical diagnosis $(n=14)$ and presence of pain for at least six months $(\mathrm{n}=12)$.

Control groups consisted of samples ranging between 20 and 1,131 subjects, with mean of 140.9 and median of 50 . The mean age of participants in control groups was 35.3 years, equivalent to that of clinical groups, and similarly varied education. In general, control groups consisted of healthy women $(n=7)$ or people with other specific conditions involving pain $(n=8)$.

The most frequent inclusion criteria for the clinical groups were duration of pain symptoms $8,20,21,24-27,29,31-36$, which ranged from three to

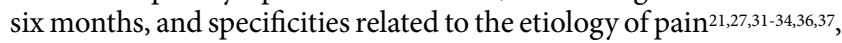
for example, pain resulting from pelvic adhesions. It is noteworthy that not all studies strictly followed the international criteria for the diagnosis of CPP, which require a minimum duration of six months for pain symptoms ${ }^{9-13}$.

Criteria for the inclusion in control groups consisted mainly of the absence of CPP20,21,27,29-36,38 and presence of other specific clinical conditions such as lower back pain and migraine $27,29,30,34,36$.
Exclusion criteria for the composition of $\mathrm{CPP}$ and control groups consisted mainly of the presence of other general (e.g.: interstitial cystitis, positive HIV, hypertension, diabetes) and/or gynecological conditions (e.g.: uterine fibroids and cysts) and pregnancy. It should be noted that nine studies $24,26-28,29,31,33,34,36$ described no exclusion criteria.

The main outcome measures assessed in the studies included (a) mood indicators $(\mathrm{n}=17)$; (b) anxiety indicators $(\mathrm{n}=9)$; and (c) somatization/dissociation indicators $(\mathrm{n}=3)$. Table 2 shows the outcome measures and assessment instruments used in the studies reviewed.

As seen in table 2, a number of different instruments were used to assess outcome variables, most of which were self-rated. Mood indicators were mainly evaluated through the Beck Depression Inventory (BDI; $\mathrm{n}=8 ; 44.4 \%$ ), with only one study that reported the use of the Structured Clinical Interview for DSM-IV (SCIDIV), regarded as the gold standard for psychiatric diagnoses. In the assessment of anxiety indicators, only the Beck Anxiety Inventory (BAI) and the Hospital Anxiety and Depression Scale (HADS) were used in more than one study. For the assessment of somatization and dissociation indicators, the SCID-IV was the main instrument of choice $(n=2)$.

The main associations between CPP and psychiatric disorders/ symptoms are shown in table 3.

The groups with CPP included in the studies had a high frequency of anxiety and depression symptoms, with respective prevalence rates of $38.6 \%$ and $29.5 \%$. Relative to control groups, CPP subjects presented higher rates of depression $(n=7)$ and anxiety $(n=3)$, regardless of the instruments used in the assessments. Comparisons between groups with CPP and endometriosis concerning depression indicators showed that subjects with CPP had a higher frequency of mood symptoms.

When CPP groups were compared to control groups with chronic lower back pain, authors reported divergent findings related to depression rates ${ }^{29,30}$, despite the fact that the two studies making these comparisons had similar sampling procedures and used the same assessment instrument. Another investigation found equivalent rates of depression and anxiety in subjects with CPP and migraine ${ }^{21}$, and two others found no differences when comparing CPP groups with different etiologies 27,37 .

There are reports of significant positive associations between CPP and anxiety, depression and dissociation indicators, pain, and physical or sexual abuse $24,25,28,29,38$. On the other hand, negative associations have been found between CPP and depression, anxiety, sexual adjustment and quality of life ${ }^{31,36}$.

Finally, bipolar affective disorder (BAD) was more prevalent in a group with endometriosis ${ }^{36}$ and post-traumatic stress disorder (PTSD) was found in $31.3 \%$ of a group of subjects with CPP26. Dissociative and somatoform symptoms were highly prevalent in samples with CPP24,33.

\section{Discussion}

This study systematically assessed the existence of associations between CPP and different psychiatric indicators/disorders through the exam of empirical articles published between 2003 and 2014.

Some remarks should be made concerning the methodological aspects of the studies included in this review, as they may affect the interpretation of the results presented. The first one refers to the study design adopted in the investigations, as $27.7 \%$ were descriptive studies. Also, there was great variability in the measures used, with a total of 18 different instruments, which hinders direct comparisons between their results. Most of the studies reviewed used screening instruments (83.4\%) based on self-report. Only three studies used the SCID-IV, a structured, clinician-rated diagnostic interview regarded as the gold standard for the establishment of psychiatric diagnoses. We conclude, therefore, that most studies assessed the presence of symptoms, and not disorders.

The fact that most studies focused on the assessment of symptoms of depression and anxiety is also noteworthy. Other disorders as, for 
Table 1. Main characteristics of the samples in the studies reviewed

\begin{tabular}{|c|c|c|c|c|c|c|c|c|c|c|c|c|c|}
\hline \multirow[b]{2}{*}{ Ref. } & \multirow[b]{2}{*}{ Authors } & \multirow[b]{2}{*}{ Country } & \multicolumn{6}{|c|}{ CPP groups } & \multicolumn{5}{|c|}{ Control groups } \\
\hline & & & N & $\begin{array}{l}\text { Mean } \\
\text { age } \\
\text { (SD) } \\
\end{array}$ & Education & $\begin{array}{c}\text { Marital } \\
\text { status }\end{array}$ & $\begin{array}{c}\text { CPP } \\
\text { diagnosis }\end{array}$ & $\begin{array}{l}\text { Duration } \\
\text { of pain }\end{array}$ & N & $\begin{array}{c}\text { Mean age } \\
\text { (SD) }\end{array}$ & Education & $\begin{array}{l}\text { Marital } \\
\text { status }\end{array}$ & $\begin{array}{c}\text { Clinical } \\
\text { characteristics }\end{array}$ \\
\hline \multirow[t]{2}{*}{29} & \multirow{2}{*}{\begin{tabular}{|c|} 
Lampe \\
et al. (2003)
\end{tabular}} & \multirow[t]{2}{*}{ Austria } & \multirow[t]{2}{*}{$43 \mathrm{~F}$} & \multirow[t]{2}{*}{$32.4(8.8)$} & \multirow[t]{2}{*}{---} & \multirow[t]{2}{*}{---} & \multirow[t]{2}{*}{--- } & \multirow{2}{*}{$\begin{array}{c}\geq 6 \\
\text { months }\end{array}$} & $40 \mathrm{~F}$ & $40(9.1)$ & --- & --- & Chronic LBP \\
\hline & & & & & & & & & $22 \mathrm{~F}$ & $29.3(8.1)$ & --- & --- & Healthy \\
\hline 24 & \begin{tabular}{|c|} 
Nijenhuis \\
et al. (2003)
\end{tabular} & $\begin{array}{c}\text { The } \\
\text { Netherlands }\end{array}$ & $52 \mathrm{~F}$ & 37.9(9.7) & --- & --- & --- & $\begin{array}{c}\geq 6 \\
\text { months }\end{array}$ & NA & NA & NA & NA & NA \\
\hline \multirow[t]{3}{*}{30} & \multirow[t]{3}{*}{$\begin{array}{c}\text { Heinberg } \\
\text { et al. (2004) }\end{array}$} & \multirow[t]{3}{*}{$\begin{array}{l}\text { United } \\
\text { States }\end{array}$} & \multirow[t]{3}{*}{$22 \mathrm{~F}$} & \multirow[t]{3}{*}{$37.8(13.7)$} & \multirow[t]{3}{*}{$\begin{array}{c}14.7 \\
\text { years }\end{array}$} & \multirow[t]{3}{*}{---} & \multirow[t]{3}{*}{---} & \multirow[t]{3}{*}{---} & $22 \mathrm{M}$ & $40.9(14.4)$ & 14.5 years & --- & $\begin{array}{c}\text { Men w/urogenital } \\
\text { pain }\end{array}$ \\
\hline & & & & & & & & & $22 \mathrm{~F}$ & $51(12.5)$ & 13.8 years & --- & Women w/LBP \\
\hline & & & & & & & & & $28 \mathrm{M}$ & 43.8(9.8) & 13.5 years & --- & Men w/LBP \\
\hline 25 & \begin{tabular}{|l|} 
Poleshuck \\
et al. (2005)
\end{tabular} & $\begin{array}{l}\text { United } \\
\text { States }\end{array}$ & $63 \mathrm{~F}$ & $39.2(11.7)$ & --- & --- & Clinical & $\begin{array}{c}\geq 6 \\
\text { months }\end{array}$ & NA & NA & NA & NA & NA \\
\hline 31 & \begin{tabular}{|c|} 
Kaya et al. \\
(2006)
\end{tabular} & Turkey & $19 \mathrm{~F}$ & $34.1(9.3)$ & --- & --- & Clinical & $\begin{array}{c}\geq 6 \\
\text { months }\end{array}$ & $25 \mathrm{~F}$ & $30.6(7.3)$ & --- & --- & Healthy \\
\hline 32 & \begin{tabular}{|l|} 
Lorençatto \\
et al. (2006)
\end{tabular} & Brazil & $50 \mathrm{~F}$ & $35.3(6.4)$ & --- & $\begin{array}{c}8 \mathrm{~S} \\
42 \mathrm{M}\end{array}$ & Clinical & $\begin{array}{c}\geq 6 \\
\text { months }\end{array}$ & $50 \mathrm{~F}$ & $32.8(7.1)$ & --- & $\begin{array}{l}22 \mathrm{~S} \\
28 \mathrm{M}\end{array}$ & Endometriosis \\
\hline 26 & \begin{tabular}{|c|} 
Meltzer- \\
Brody et al. \\
$(2007)$
\end{tabular} & $\begin{array}{l}\text { United } \\
\text { States }\end{array}$ & $713 F$ & $35.3(9.8)$ & $\begin{array}{c}14.9 \\
\text { years }\end{array}$ & --- & Clinical & $\begin{array}{c}\geq 6 \\
\text { months }\end{array}$ & NA & NA & NA & NA & NA \\
\hline 20 & \begin{tabular}{|c|} 
Romão \\
et al. (2009)
\end{tabular} & Brazil & $52 \mathrm{~F}$ & $31.7(8.1)$ & $\begin{array}{c}\text { 12BE; } \\
18 \mathrm{ES} ; \\
19 \mathrm{HS} ; \\
3 \mathrm{SE}\end{array}$ & --- & Clinical & $\begin{array}{c}\geq 6 \\
\text { months }\end{array}$ & $54 \mathrm{~F}$ & $30.3(6.2)$ & $\begin{array}{c}\text { 9BE; 19ES; } \\
\text { 25HS; } \\
\text { 1SE }\end{array}$ & --- & Healthy \\
\hline 33 & $\begin{array}{l}\text { Wingenfeld } \\
\text { et al. (2009) }\end{array}$ & Germany & $18 \mathrm{~F}$ & --- & --- & --- & Clinical & $\begin{array}{c}\geq 4 \\
\text { months }\end{array}$ & $24 \mathrm{~F}$ & --- & --- & --- & Healthy \\
\hline \multirow[t]{2}{*}{34} & \multirow{2}{*}{\begin{tabular}{|c|} 
Kumar \\
et al. (2010)
\end{tabular}} & \multirow[t]{2}{*}{ India } & \multirow[t]{2}{*}{$100 \mathrm{~F}$} & \multirow[t]{2}{*}{---} & \multirow[t]{2}{*}{---} & \multirow[t]{2}{*}{---} & Clinical & $\geq 6$ & $100 \mathrm{~F}$ & --- & --- & --- & Endometriosis \\
\hline & & & & & & & & months & $100 \mathrm{~F}$ & --- & --- & --- & Healthy \\
\hline 35 & \begin{tabular}{|c|} 
Barcelos \\
et al. $(2010)$
\end{tabular} & Brazil & $30 \mathrm{~F}$ & $35.2(7.5)$ & 7.5 years & $22 \mathrm{M}$ & Clinical & $\begin{array}{c}\geq 6 \\
\text { months }\end{array}$ & $20 \mathrm{~F}$ & $36(9.3)$ & 8.5 years & $13 \mathrm{M}$ & $\begin{array}{l}\text { Other gynecological } \\
\text { conditions }\end{array}$ \\
\hline 36 & \begin{tabular}{|c|} 
Kumar \\
et al. (2011)
\end{tabular} & Canada & $12 \mathrm{~F}$ & 35.6(---) & --- & --- & \begin{tabular}{|c|} 
Clinical + \\
laparoscopy \\
\end{tabular} & $\begin{array}{c}\geq 6 \\
\text { months }\end{array}$ & $27 \mathrm{~F}$ & 30.3(---) & --- & --- & Endometriosis \\
\hline 8 & $\begin{array}{c}\text { Silva et al. } \\
\text { (2011) }\end{array}$ & Brazil & $147 \mathrm{~F}$ & $40.4(15)$ & $54 \mathrm{ES}$ & $\begin{array}{c}15 \mathrm{~S} \\
8 \mathrm{D} \\
31 \mathrm{M} \\
\end{array}$ & Clinical & $\begin{array}{c}\geq 6 \\
\text { months }\end{array}$ & $1,131 \mathrm{~F}$ & $43(15.6)$ & $305 \mathrm{ES}$ & $\begin{array}{l}402 \mathrm{~S} \\
225 \mathrm{D} \\
504 \mathrm{M} \\
\end{array}$ & Healthy \\
\hline 27 & \begin{tabular}{|c|} 
Souza et al. \\
(2011)
\end{tabular} & Brazil & $57 \mathrm{~F}$ & $35.8(8.6)$ & --- & --- & Clinical & $\begin{array}{c}>6 \\
\text { months }\end{array}$ & NA & NA & NA & NA & NA \\
\hline 21 & \begin{tabular}{|l} 
Roth et al. \\
(2011a)
\end{tabular} & $\begin{array}{l}\text { United } \\
\text { States }\end{array}$ & $39 F$ & $33.5(10.5)$ & 4.9 years & --- & Clinical & $\begin{array}{c}>3 \\
\text { months }\end{array}$ & $38 \mathrm{~F}$ & $\begin{array}{c}36.3 \\
(11.1)\end{array}$ & 5.4 years & --- & Migraine \\
\hline 37 & Roth et al. & United & $30 \mathrm{~F}$ & --- & --- & --- & Clinical + & --- & $70 \mathrm{~F}$ & --- & --- & --- & Myofascial pain \\
\hline & (2011b) & States & & & & & laparoscopy & & $38 \mathrm{~F}$ & --- & --- & --- & Pelvic adhesions \\
\hline 38 & \begin{tabular}{|c|} 
Demir et al. \\
(2012)
\end{tabular} & Turkey & $44 \mathrm{~F}$ & $35.6(9.9)$ & $\begin{array}{c}35 \mathrm{ES} ; 9 \\
\mathrm{HS}\end{array}$ & --- & --- & --- & $31 \mathrm{~F}$ & $38.8(4.2)$ & $\begin{array}{c}26 \mathrm{ES} \\
5 \mathrm{HS}\end{array}$ & --- & Healthy \\
\hline 28 & $\begin{array}{c}\text { As-Sanie } \\
\text { et al. (2014) }\end{array}$ & $\begin{array}{l}\text { United } \\
\text { States }\end{array}$ & $273 F$ & $34.8(11.3)$ & $\begin{array}{c}11 \mathrm{BE} ; \\
126 \mathrm{HS} ; \\
136 \mathrm{SE}\end{array}$ & $\begin{array}{c}97 \mathrm{~S} ; \\
139 \\
\mathrm{M} ; 23 \\
\mathrm{D} ; 14 \\
\text { other }\end{array}$ & Clinical & --- & NA & NA & NA & NA & NA \\
\hline
\end{tabular}

M: married; D: divorced; S: single; CPP: chronic pelvic pain; BE: basic education; ES: elementary school; HS: high school; SE: superior education; F: female; M: male; LBP: lower back pain; NA: not applicable.

example, dysthymia and personality disorders, among others, were not contemplated, and attention to these conditions could be relevant for a better comprehension of psychic conditions associated with CPP.

Specifically in respect to the results of the studies reviewed, investigations using a case-control design enrolled healthy subjects and/or subjects with other pathological conditions associated or not with the presence of pain in their control groups. When assessing the prevalence rates reported in descriptive studies, depression and anxiety rates $(29.5 \%$ ad $38.6 \%$, respectively) are much higher than those found in the general population by a recent Brazilian epidemiological survey $(9.4 \% \text { and } 19.9 \% \text {, respectively })^{39}$. These rates are also higher than those reported by international epidemiological studies, as the one by Kessler et al.40 in which the lifetime rates of depression and anxiety were respectively $18.3 \%$ and $21.4 \%$ in an adult population. This large difference should be regarded with caution since the studies reviewed here assessed symptoms and not the presence of disorders as in epidemiological surveys. Still, however, the rates are high and should be considered as signs of increased difficulties.

Studies involving control groups formed by healthy subjects found that depression was more prevalent among women with CPP $(n=7)$, regardless of the instruments used to measure depression indicators. The same result was found by studies comparing anxiety in women with CPP and healthy women $(n=3)$, with the exception of the study by Kaya et al.32, where no differences were found. 
Table 2. Outcome variables and instruments used in the studies ( $N=19$; non-exclusive categories)

\begin{tabular}{|c|c|c|c|}
\hline \multicolumn{3}{|l|}{ Outcome variables } & \multirow{3}{*}{$\begin{array}{l}\text { Instruments } \\
\text { BDI }(\mathrm{N}=8)^{21,27,29-32,37,38} \\
\text { BSI }(\mathrm{N}=1)^{25,37} \\
\text { HADS }(\mathrm{N}=2)^{20,24} \\
\text { CESD }(\mathrm{N}=1)^{28,30} \\
\text { SRDS }(\mathrm{N}=1)^{33} \\
\text { DDS }(\mathrm{N}=1)^{34} \\
\text { SCID-IV }(\mathrm{N}=1)^{36} \\
\text { Self-report }(\mathrm{N}=1)^{35} \\
\text { Semi/structured interview }(\mathrm{N}=1)^{8}\end{array}$} \\
\hline \multirow{5}{*}{$\begin{array}{l}\text { Psychiatric symptoms } \\
\text { and disorders } \\
(\mathrm{N}=18)\end{array}$} & \multirow[t]{2}{*}{$\begin{array}{l}\text { Mood disorders/symptoms } \\
(\mathrm{N}=17)\end{array}$} & $\begin{array}{l}\text { Depression/depressive symptoms: } \\
\mathrm{N}=168,20,21,24,25,27-35,37,38\end{array}$ & \\
\hline & & BAD: $N=1$ & \\
\hline & \multirow[t]{2}{*}{$\begin{array}{l}\text { Anxiety disorders/symptoms } \\
(\mathrm{N}=9)\end{array}$} & $\begin{array}{l}\text { Anxiety symptoms: } \\
\mathrm{N}=88,2,21,24,25,27,31,38\end{array}$ & \multirow{2}{*}{$\begin{array}{l}\text { BAI }(N=2)^{31,38} \\
\text { HADS }(N=2)^{20,24} \\
\text { BSI }(N=1)^{25} \\
\text { SPAN }(N=1)^{26} \\
\text { STAI }(N=2)^{21,31} \\
\text { HARS }(N=1)^{27} \\
\text { Semi/structured interview }(N=1)^{8}\end{array}$} \\
\hline & & PTSD: $N=126$ & \\
\hline & $\begin{array}{l}\text { Somatization/ } \\
\text { dissociation } \\
(\mathrm{N}=3)\end{array}$ & $\mathrm{N}=324,33,38$ & $\begin{array}{l}\text { STSD }(N=1)^{24} \\
\text { SCID IV }(N=2)^{24,33} \\
\text { SDQ }(N=1)^{24} \\
\text { DES }(N=1)^{24} \\
\text { IPPS }(N=1)^{38}\end{array}$ \\
\hline
\end{tabular}

BAI: Beck Anxiety Inventory; BDI: Beck Depression Inventory; BSI: Brief Symptom Inventory; CESD: Center for Epidemiological Studies - Depression scale; DDS: Deep Depression Scale; DES: Dissociative Experiences Scale; HADS: Hospital Anxiety and Depression Scale; HARS: Hamilton Anxiety Rating Scale; IPPS: International Pelvic Pain Society questionnaire, SCID-IV: Structured Clinical Interview for DSM-IV; SDQ: Somatoform Dissociation Questionnaire; SPAN: Startle, Physiological Arousal, Anger and Numbness scale; SRDS: Self-Rating Depression Scale; STAI: State-Trait Anxiety Inventory; STSD: Screening Test for Somatization Disorder; BAD: Bipolar Affective Disorder; PTSD: Post-traumatic Stress Disorder.

Table 3. Main associations between CPP and psychiatric disorders and symptoms reported in the studies, with outcome variables as parameters

\begin{tabular}{|c|c|c|c|}
\hline \multirow[t]{5}{*}{$\begin{array}{l}\text { Psychiatric } \\
\text { disorders } \\
\text { and } \\
\text { symptoms } \\
\text { ( } \mathrm{N}=18)\end{array}$} & \multirow[t]{2}{*}{$\begin{array}{l}\text { Mood } \\
\text { disorders/ } \\
\text { symptoms } \\
\text { (N = 17) }\end{array}$} & $\begin{array}{l}\text { Depression/ } \\
\text { depressive } \\
\text { symptoms: } \\
\mathrm{N}=16\end{array}$ & 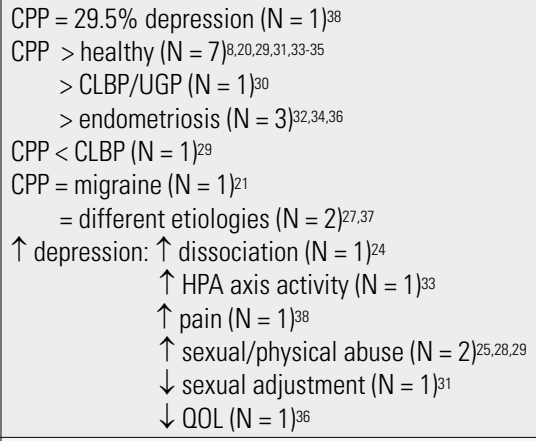 \\
\hline & & BAD: $N=1$ & $\mathrm{CPP}<$ endometriosis $(\mathrm{N}=1)^{36}$ \\
\hline & \multirow[t]{2}{*}{\begin{tabular}{|l|} 
Anxiety \\
disorders/ \\
symptoms \\
$(\mathrm{N}=9)$
\end{tabular}} & $\begin{array}{l}\text { Anxiety } \\
\text { symptoms: } \\
\mathrm{N}=8\end{array}$ & $\begin{array}{l}\mathrm{CPP}=38.6 \% \text { anxiety }(\mathrm{N}=1)^{38} \\
\mathrm{CPP}>\text { healthy }(\mathrm{N}=3)^{8,20,35} \\
\mathrm{CPP}=\text { healthy }(\mathrm{N}=1)^{31} \\
=\text { migraine }(\mathrm{N}=1)^{21} \\
=\text { different etiologies }(\mathrm{N}=1)^{27} \\
\begin{aligned} \uparrow \text { anxiety: } & \uparrow \text { dissociation }(\mathrm{N}=1)^{24} \\
& \uparrow \text { sexual/physical abuse }(\mathrm{N}=1)^{25} \\
& \uparrow \text { pain }(\mathrm{N}=1)^{38} \\
& \downarrow \text { sexual adjustment }(\mathrm{N}=1)^{31} \\
& \downarrow \mathrm{OOL}(\mathrm{N}=1)^{36}\end{aligned}\end{array}$ \\
\hline & & PTSD: $\mathrm{N}=1$ & $\mathrm{CPP}=31.3 \% \mathrm{PTSD}(\mathrm{N}=1)^{26}$ \\
\hline & $\begin{array}{l}\text { Somatization/ } \\
\text { dissociation } \\
(\mathrm{N}=3)\end{array}$ & \multicolumn{2}{|c|}{$\begin{array}{l}\mathrm{CPP}=26.9 \% \text { dissociative symptoms }(\mathrm{N}=1)^{24} \\
\mathrm{CPP}=100 \% \text { somatoform pain }(\mathrm{N}=1)^{33} \\
\quad=6.8 \% \text { somatization disorder }(\mathrm{N}=1)^{38} \\
\begin{aligned} & \uparrow \text { dissociation: } \uparrow \text { somatization }(\mathrm{N}=1)^{24} \\
& \uparrow \text { traumatic experiences }(\mathrm{N}=1)^{24}\end{aligned}\end{array}$} \\
\hline
\end{tabular}

<: lower; > : higher; $\uparrow$ : increased; $\downarrow$ : decreased; CLBP: chronic lower back pain; CPP: chronic pelvic pain; UGP: urogenital pain; HPA: hypothalamic-pituitary-adrenal; Q0L: quality of life; BAD: bipolar affective disorder; PTSD: post-traumatic stress disorder.

Few studies included in the review $(n=5)$ compared groups with $\mathrm{CPP}$ and groups of subjects with specific pathologies that included pain as a symptom (namely, lower back and/or urogenital pain, migraine, and endometriosis) in an attempt to ascertain the influence of this variable. These investigations used common instruments and suggest that depression indicators tend to be more frequent in CPP groups, which opens the perspective to think of the existence of particular characteristics of CPP that associate with depression besides pain alone. In relation to anxiety, this type of comparative study is still scarce and do not allow for conclusions. 
It should be noted that indicators of depression and anxiety varied between groups of CPP with different etiologies (endometriosis, myofascial pain, pelvic adhesions etc.), with inconclusive results from the different studies in the area.

Bipolar affective disorder was found in $44.4 \%$ of women with CPP associated with endometriosis, while no women with CPP without endometriosis presented this psychiatric condition. The fact that the rate of BAD in the general Brazilian population was estimated in $1.5 \%{ }^{39}$ makes it difficult to explain the high frequency of this condition in the CPP group with associated endometriosis. However, if we consider CPP alone, the rate of $\mathrm{BAD}$ is close to that of the general population, or even smaller.

In CPP groups, the results available show associations of the condition with rates of depression and anxiety and increased presence of dissociation, pain, and physical and/or sexual abuse. On the other hand, reduced sexual adjustment and quality of life were negatively associated with these rates. These data raise the hypothesis of a possible chain reaction in which trauma, such as sexual abuse in childhood, could contribute to the etiology of CPP and also to the increase in depressive and dissociative experiences and somatic conditions ${ }^{25,28,29}$, in addition to having a negative impact on quality of life and sexual adjustment. The experience of these impairments and difficulties may feed back the chain, favoring experiences of anxiety and depression, which may also act as risk factors for the increase in experiences of pain, especially of somatic origin.

Along the same line, PTSD was observed in $31.3 \%$ of women with CPP, once again a high rate as compared with national ${ }^{39}$ and international 40 data pointing to prevalence rates of $1.6 \%$ and $8 \%$, respectively, in the general population. By relating these findings to the significant rates of dissociative symptoms and somatoform pain in CPP groups, we can again hypothesize that trauma might be a risk factor for the development of CPP. Only one study ${ }^{28}$, however, included logistic regression in its analysis. Future studies with this focus are therefore extremely necessary to provide evidence concerning the predictive role of trauma in the development of CPP.

In conclusion, depressive symptoms tend to be more present in CPP and this relationship does not seem to be specifically connected to pain, a core feature of CPP. Other factors particular to CPP seem to be implicated in this association. In this review, we found that traumatic experiences in childhood or adult life are some of the aspects that deserve attention. Also, anxiety and other specific disorders assessed, such as BAD, PTSD, and somatization disorder, require further investigation for the establishment of their role in CPP.

Directions for future research include: (a) greater methodological refinement involving other study designs, such as logistic regression, to investigate the impact of specific variables like early trauma; (b) detailed assessment of variables related to the duration and intensity of pain; and (c) use of diagnostic instruments with greater specificity and reliability.

\section{Acknowledgment}

This study received funding from National Council for Scientific and Technological Development (CNPq - Process No. 471441/2012-0).

\section{References}

1. Mathias SD, Kuppermann M, Liberman RF, Lipschutz RC, Steege JF. Chronic pelvic pain: prevalence, health-related quality of life, and economic correlates. Obstet Gynecol. 1996; 87(3):321-7.

2. Howard FM. Chronic pelvic pain. Obstet Gynecol. 2003;101(3):594-611.

3. Nogueira AA, Reis FJC, Poli-Neto OB. Abordagem da dor pélvica crônica em mulheres. Rev Bras Ginecol Obstet. 2006;28(12):733-40.

4. Zondervan KT, Yudkin PL, Vessey MP, Jenkinson CP, Dawes MG, Barlow D. et al. The community prevalence of chronic pelvic pain in women and associated illness behaviour. Br J Gen Pract. 2001;51(468):541-7.

5. Grace VM, Zondervan KT. Chronic pelvic pain in New Zealand: prevalence, pain severity, diagnoses and use of the health services. Aust N Z J Public Health. 2004;28(4):369-75.
6. Latthe P, Latthe M, Say L, Gulmezoglu M, Khan KS. WHO systematic review of prevalence of chronic pelvic pain: a neglected reproductive health morbidity. BMC Public Health. 2006;6,177.

7. Pitts MK, Ferris JA, Smith AM, Shelley JM, Richters J. Prevalence and correlates of three types of pelvic pain in a nationally representative sample of Australian women. Med J Aust. 2008;189(3):138-43.

8. Silva GP, Nascimento AL, Michelazzo D, Alves Junior FF, Rocha MG, Silva JC, et al. High prevalence of chronic pelvic pain in women in Ribeirão Preto, Brazil and direct association with abdominal surgery. Clinics. 2011;66(8):1307-12.

9. Howard FM. The role of laparoscopy in chronic pelvic pain: promise and pitfalls. Obstet Gynecol Sur. 1993;48(6):357-87.

10. Campbell F, Collett BJ. Chronic pelvic pain. Br J Anaesth. 1994;73(5): 571-3.

11. Gelbaya TA, El-Halwagy HE. Focus on primary care: chronic pelvic pain in women. Obstet Gynecol Sur. 2001;56(12):757-64.

12. American Congress of Obstetricians and Gynecologists. Practice Bulletin No. 51. Chronic pelvic pain. Obstet Ginecol. 2004;103:589-605.

13. Williams RE, Hartmann KE, Steege JF. Documenting the current definitions of chronic pelvic pain: implications for research. Obstet Gynecol. 2004;103(4):686-91.

14. Romão APMS, Romão GS, Gorayeb R, Nogueira AA. O funcionamento psicológico e sexual da mulher com dor pélvica crônica: atualização. Femina. 2009;37(1):19-22.

15. Latthe P, Mignini L, Gray R, Hills R, Khan K. Factors predisposing women to chronic pelvic pain: systematic review. Br Med J. 2006;332(7544):74955 .

16. Harrop-Griffiths J, Katon W, Walker E, Holm L, Russo J, Hickok L. The association between chronic pelvic pain, psychiatric diagnoses, and childhood sexual abuse. Obstet Gynecol. 1988;71(4):589-94.

17. Hodgkiss AD, Sufraz R, Watson JP. Psychiatric morbidity and illness behaviour in women with chronic pelvic pain. J Psychosom Res. 1994;38(1):3-9.

18. Walker EA, Katon WJ, Hansom J, Harrop-Griffiths J, Holm L, Jones ML, et al. Psychiatric diagnoses and sexual victimization in women with chronic pelvic pain. Psychosomatics. 1995;36(6):531-40.

19. Wiech K, Tracey I. The influence of negative emotions on pain: behavioral effects and neural mechanisms. NeuroImage. 2009;47(3):987-94.

20. Romão AP, Gorayeb R, Romão GS, Poli-Neto OB, dos Reis FJ, Rosa-e-Silva JC, et al. High levels of anxiety and depression have a negative effect on quality of life of women with chronic pelvic pain. Int J Clin Pract. 2009;63(5):707-11.

21. Roth RS, Punch MR, Bachman JE. Psychological factors and chronic pelvic pain in women: a comparative study with women with chronic migraine headaches. Health Care for Women Int. 2011;32(8):746-61.

22. Fry RP, Crisp AH, Beard RW, McGuigan S. Psychosocial aspects of chronic pelvic pain, with special reference to sexual abuse. A study of 164 women. Postgrad Med J. 1993;69(813):566-74.

23. Fishbain, DA, Cutler R, Rosomoff HL, Rosomoff RS. Chronic pain associated depression: antecedent or consequence of chronic pain? A review. Clin J Pain. 1997;13(2):116-37.

24. Nijenhuis ER, van Dyck R, ter Kuile MM, Mourits MJ, Spinhoven P, van der Hart $\mathrm{O}$. Evidence for associations among somatoform dissociation, psychological dissociation and reported trauma in patients with chronic pelvic pain. J Psychosom Obstet Gynecol. 2003;24(2):87-98.

25. Poleshuck EL, Dworkin RH, Howard FM, Foster DC, Shields CG, Giles DE, et al. Contributions of physical and sexual abuse to women's experiences with chronic pelvic pain. J Reprod Med. 2005;50(2):91-100.

26. Meltzer-Brody S, Leserman J, Zolnoun D, Steege J, Green E, Teich A. Trauma and posttraumatic stress disorder in women with chronic pelvic pain. Obstet Gynecol. 2007;109(4):902-8.

27. Souza CA, Oliveira LM, Scheffel C, Genro VK, Rosa V, Chaves MF, et al. Quality of life associated to chronic pelvic pain is independent of endometriosis diagnosis--a cross-sectional survey. Health Qual Life Outcomes. 2011;10(9):41-6.

28. As-Sain, Clevenger LA, Geisser ME, Williams DA, Roth RS. History of abuse and its relationship to pain experience and depression in women with chronic pelvic pain. Am J Obstet Gynecol. 2014;210(4):317.e1-8.

29. Lampe A, Doering S, Rumpold G, Sölder E, Krismer M, Kantner-Rumplmair W, et al. Chronic pain syndromes and their relation to childhood abuse and stressful life events. J Psychosom Res. 2003;54(4):361-7. 
30. Heinberg LJ, Fisher BJ, Wesselmann U, Reed J, Haythornthwaite JA. Psychological factors in pelvic/urogenital pain: the influence of site of pain versus sex. Pain. 2004;108(1-2):88-94.

31. Kaya B, Unal S, Ozenli Y, Gursoy N, Tekiner S, Kafkasli A. Anxiety, depression and sexual dysfunction in women with chronic pelvic pain. Sex Relationship Ther. 2006;21(2):187-96.

32. Lorençatto C, Petta CA, Navarro MJ, Bahamondes L, Matos A. Depression in women with endometriosis with and without chronic pelvic pain. Acta Obstet Gynecol Scand. 2006;85(1):88-92.

33. Wingenfeld K, Hellhammer DH, Schmidt I, Wagner D, Meinlschmidt G, Heim C. HPA axis reactivity in chronic pelvic pain: association with depression. J Psychosom Obstet Gynecol. 2009;30(4):282-6.

34. Kumar A, Gupta V, Maurya A. Mental health and quality of life of chronic pelvic pain and endometriosis patients. J Project Psychol Mental Health. 2010;17(2):153-7.

35. Barcelos PR, Conde DM, Deus JM, Martinez EZ. Qualidade de vida de mulheres com dor pélvica crônica: um estudo de corte transversal analítico. Rev Bras Ginecol Obstet. 2010;32(5):247-53.
36. Kumar V, Khan M, Vilos GA, Sharma V. Revisiting the association between endometriosis and bipolar disorder. J Obstet Gynecol Can. 2011;33(11):1141-5.

37. Roth RS, Punch M, Bachman JE. Psychological factors in chronic pelvic pain due to endometriosis: a comparative study. Gynecol Obstet Invest. 2011;72(1):15-9.

38. Demir F, Ozcimen EE, Oral HB. The role of gynecological, urological, and psychiatric factors in chronic pelvic pain. Arch Gynecol Obstet. 2012;286(5):1215-20.

39. Andrade LH, Wang Y, Andreoni S, Silveira CM, Alexandrino-Silva C, Siu ER, et al. Mental disorders in megacities: findings from the São Paulo Megacity Mental Health Survey, Brazil. Plos One. 2012;7:132837.

40. Kessler RC, Petukhova M, Sampson NA, Zaslavsky AM, Wittchen HU. Twelve-month and lifetime prevalence and lifetime morbid risk of anxiety and mood disorders in the United States. Int J Methods Psychiatr Res. 2012;21:169-84. 